\title{
Pituitary Gland Mixed Acidophil-Basophil Adenoma
}

National Cancer Institute

\section{Source}

National Cancer Institute. Pituitary Gland Mixed Acidophil-Basophil Adenoma. NCI

Thesaurus. Code C4148.

An epithelial neoplasm of the anterior pituitary gland in which the neoplastic cells stain positive with acidic and basic dyes. 